\title{
Children's Friendly TPA (TPA)
}

\author{
Erny Wahdini ${ }^{1}$, Suhaimi ${ }^{2 *}$, Amberansyah ${ }^{3}$
}

\begin{abstract}
${ }^{1}$ Early Childhood Teacher Education, Lambung Mangkurat University Jl. Brigjen H. Hasan Basri, Pangeran, Kec. North Banjarmasin, Banjarmasin City, South Kalimantan 70123, Indonesia

${ }^{2}$ Education Management, Lambung Mangkurat University Jl. Brigjen H. Hasan Basri, Pangeran, Kec. North Banjarmasin, Banjarmasin City, South Kalimantan 70123, Indonesia

${ }^{3}$ Elementary School Teacher Education, Lambung Mangkurat University Jl. Brigjen H. Hasan Basri, Pangeran, Kec. North Banjarmasin, Banjarmasin City, South Kalimantan 70123, Indonesia
\end{abstract}

\section{Abstract}

In an effort to implement expansion of access to early childhood education, various policies have been issued by the government ranging from the statutory system to matters of a technical operational nature. One of the government policies in the education sector that supports lifelong education is the recognition of Early Childhood Education (PAUD). So far, the management of non-formal PAUD is still less professional, especially for the coaches or teachers, so that teachers who have the competence and certification are urgently needed as teachers of non-formal PAUD. This study aims to reveal the implementation of a child-friendly Child Care Park (TPA). The research method used is qualitative research (Qualitative Research) with a naturalistic phenomenological approach. This is expected to be a solution to gain a deep understanding of planning, implementation, monitoring, and evaluation of the meaning of phenomena that occur in the field.

Keywords: PAUD, TPA, non formal.

Copyright (C) 2021 The Author(s): This is an open-access article distributed under the terms of the Creative Commons Attribution 4.0 International License (CC BY-NC 4.0) which permits unrestricted use, distribution, and reproduction in any medium for non-commercial use provided the original author and source are credited.

\section{INTRODUCTION}

Definition of education. According to Djumali [1], "education is to prepare humans to solve life problems in the present and in the future". According to Sutrisno [2], education is an activity that is linked, and includes various elements that are closely related between one element and another. Education also has a juridical definition in Law Number 20 of 2003 concerning the National Education System which states: Education is a conscious and planned effort to create an atmosphere of learning and the learning process so that students actively develop their potential to have religious spiritual power, self-control, personality, intelligence, noble character, and skills needed for himself, society and the nation.

According to Kurniawan [3], education is transferring values, knowledge, experience and skills to the younger generation as an effort for the older generation to prepare the life functions of the next generation, both physically and spiritually. H. Mangun Budiyanto, as quoted by Kurniawan [3], "believes that education is preparing and growing students or human individuals whose processes are ongoing from birth to death". According to Trahati [4], education is an activity carried out by humans consciously and programmed to build a good personality and develop the abilities or talents that exist in individual humans in order to achieve certain goals or targets in life. Based on the description above, it can be concluded that education is an effort to prepare and equip the younger generation with knowledge, experience and ability to solve problems whose processes take place from birth to the end of life, both physically and spiritually.

Taman Penitipan Children as "substitute families" are expected to provide welfare development and educational services for early childhood to achieve optimal growth and development [5]. Therefore, in its implementation, in addition to implementing childcare activities for a certain period of time, it is also necessary to carry out educational activities that refer to the Regulation of the Minister of Education and Culture of the Republic of Indonesia number 146 concerning the 2013 PAUD Curriculum. This shows that the Child Care Park is not only for improving children's welfare but also for developing various potentials of children from an early age in a certain time as preparation for life and being able to adapt to their environment. 
Erny Wahdini et al., J Adv Educ Philos, Apr, 2021; 5(4): 110-115

The theory of Empiricism by Locke states that every individual who is born is like a white paper, and then the environment will write the white paper. Then Shopen's theory of Nativism explains the philosophical teachings of nativism, which are classified as idealism, which concludes that personal development is only determined by heredity, an internal factor, which means nature. In the end, based on the two theories above, Stern's Convergence theory emerged, which argued that humans are not just a piece of white paper that can be written on, but humans also inherit traits from parents which are inherited from birth. Therefore, personal development is actually the result of a collaborative process between the two factors (internal factors / heredity, and external / environmental factors, education). Watson experimented that through education and training, children can become doctors, lawyers, artists, businessmen, leaders, or beggars and even thieves without neglecting the talents, tendencies of talent / work skills, hobbies, and race of the ancestors. Had this experiment been permitted, Watson could determine the way in which children would be raised and what world would shape them.

The limitations of the government in holding formal PAUD such as Kindergarten and Raudatul Atfal, of course are greatly helped by the presence of nonformal PAUD. In addition, the socialization of nonformal PAUD must be intensified so that the Indonesian people are not ordinary with that. The concept of the benefits of empowered PAUD is none other than the more ready our children are to enter the primary education level (elementary school).

The PAUD management process includes at least 4 stages as according to terry's management function, which is usually abbreviated as POAC, namely:

a) Planning (planning), planning according to Newman followed by Manulang [6]. "Planning is deciding in advance what is to be done". Which means planning is determining in advance what will be done. PAUD institutions plan what activities will be carried out to achieve the stated goals. The planning function includes determining the vision, mission, defining objectives, establishing strategies, and developing PAUD institutions.

b) Organizing (organizing), the manager / manager determines the tasks that must be carried out, who has to do it, classifies tasks, who reports to whom, and at which level policy making is carried out.

c) Deployment (actuating), the manager / manager moves all related people to jointly carry out activities in accordance with their respective duties, motivate subordinates, direct, select, and resolve conflicts that arise wisely. To motivate educators and other staff to work optimally is to apply motivation. This means that the principal stimulates the teacher and other staff to be motivated to do the work.

d) Supervision (controlling), the manager / manager controls and exerts control over the implementation of these activities, so that they can achieve targets effectively and efficiently. Control includes monitoring activities of subordinates, both control of discipline, responsibility, and work results. Furthermore, supervision and supervision tries to find obstacles that occur so that they can be overcome immediately.

\section{RESEARCH METHODS \\ Approach and Type of Research}

This research is categorized as qualitative research with a naturalistic phenomenological approach. According to Bogdan and Taylor, qualitative research is a research procedure that produces descriptive data in the form of words or writings and the behavior of the people being observed. According to them, this approach is directed at the background and the individual holistically (intact). So in this case, it is not permissible to isolate individuals or organizations into variables or hypotheses, but it is necessary to view them as part of a whole[7].

The special character of qualitative research seeks to reveal the uniqueness of a particular individual, group, society or organization in daily life in a comprehensive and detailed manner. This approach is a research method that is expected to produce a description of the words, writings, or observable behavior of an individual, group, community or organization in a particular setting. All of them are studied from a complete, comprehensive and holistic perspective, Bogdan \& Taylor [11].

The choice of this research approach is based on the consideration that the data to be searched for is data that describes the management of the implementation of the Child Care Park in PAUD Tutwuri Handayani II Martapura. Besides, this approach aims to gain a deep understanding of the meaning of the phenomena that occur in the field. To find out in detail about the various phenomena of educational service occurring in Tutwuri Handayani II PAUD, this research uses a case study design. Bogdan and Biklen [11] suggest that a case study is a detailed study of one setting, or one subject, or one place. Storage of documents or one particular event. The basis of using case studies makes it possible for the researcher to maintain a holistic and meaningful characteristic of observed real-life events.

\section{RESEARCH SETTINGS}

This research was conducted at the Tutwuri Handayani II Martapura Early Childhood Education Institute in the Child Care Park (TPA) program in 
Erny Wahdini et al., J Adv Educ Philos, Apr, 2021; 5(4): 110-115

Banjar district for the following reasons and considerations:

1. PAUD Tutwuri Handayani II Martapura which is located at Jalan Pendidikan number 01, Jawa Martapura sub-district has been operating since July 1, 2003 in the 2003/3004 academic year. The majority of children who are included in the TPA program have their parents residing in the Martapura and Banjarbaru areas.

2. PAUD Tutwuri Handayani II Martapura is the only PAUD institution that combines the implementation of Non-formal PAUD (Playgroup and Child Care Park) which is hierarchically under the guidance of the Directorate of Early Childhood Education at the central level, at the provincial level under the guidance of the PNFI sector managed by the Satker Education for the Children at the Education Office, and at the district / city level, is under the guidance of the PNFI sector of the Education Office in charge of early childhood education and Formal PAUD (Kindergarten), which are hierarchically under the guidance of the TK / SD Directorate at the central level. at the provincial level it is under the guidance in the TK / SD sector of the Education Office and at the district / city level it is under the guidance in the $\mathrm{TK} / \mathrm{SD}$ sector.

3. The vision of PAUD Tutwuri Handayani II Martapura is to realize children who are ready to enter basic education based on faith and piety, self-confidence, virtue, and with polite behavior. With the mission carried out is a) Carry out a quality learning process, produce high achieving students, b) Carry out a learning process with religious nuances and Islami. c) Develop a skillful learning process.

\section{Types and Sources of Data}

The type of data collected in this study is qualitative data. This research is categorized as qualitative research (Qualitative Research) with a naturalistic phenomenological approach, according to Bogdan and Taylor states that qualitative research is a research procedure that produces descriptive data in the form of words or writings and people's behavior. Observed [7]. The main data comes from research subjects, namely components involved in Early Childhood Education activities in the Tutwuri Handayani II Child Care Park Program, both managers, educators, parents and students. The determination of research subjects is determined based on relevance to the research objectives, so that the selection of people as research subjects is not fixed in a standard manner but is flexible in accordance with the phenomena that occur in the field, with conditions that must be met, namely being honest, trustworthy, obeying promises, having knowledge and experience about the research background, excluding group members who conflict with the research background [8].

Data collection procedures
Data collection procedures in this study were adjusted to the formulation of the problem and research objectives. In qualitative research, data sources are selected and adjusted to the formulation of the problem and research objectives. While the data collection process prioritizes emic perspective, that is prioritizing respondents' views, namely the way they perceive or interpret the world in their stand. Meanwhile, in the social context, which includes activities, actors of activities, and places of activities are sources of data and appropriate activities are sources of data.

The data were collected through observation, interview and documentation. Observations are made openly and directly, relating to the teaching and learning process. The observation begins with a comprehensive observation (grand tour) and then becomes more focused (mini tour). Comprehensive observations were made to obtain field notes to answer common questions. Focused observation is carried out to answer questions about the unit of experience that are more detailed, detailed and describe more specific information. Interviews to gather information from managers, educators, and parents which include questions about the manager's perceptions of planning, implementation, supervision, workforce, learning, and financing and evaluation of the success of TutWuri Handayani II Child Care Park. The documentation carried out in this study is official documentation of the institution as physical evidence of an activity that has been carried out, which can be in the form of notes and photos of activities.

\section{Data Validity Check Techniques}

The method used in testing the validity of the data or checking the validity of the data is to extend the research period, continuous observation of triangulation, both triangulation of data sources, and triangulation of data collection techniques, and talking with others $[9,8]$. The following is the technical analysis picture used in the research.

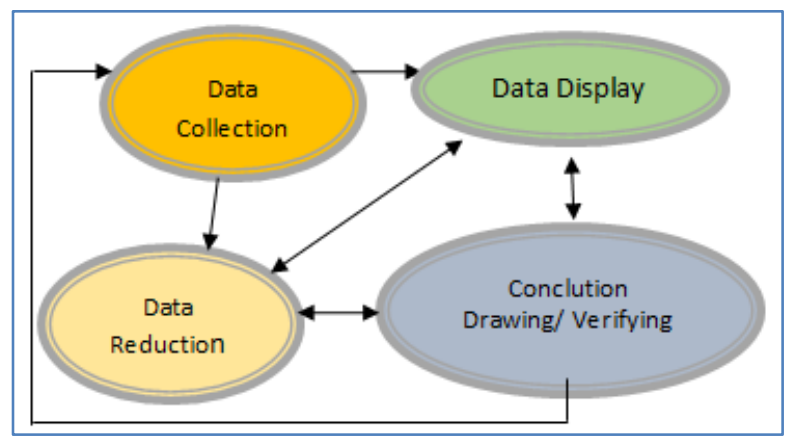

Gambar-1: Analysis Interactive Model [10]

\section{RESULTS AND DISCUSSION \\ Objective Conditions of Research Location}

This research was conducted at PAUD Tutwuri Handayani II Martapura which is located at Jl. Education Gang Pendidikan II Banjar Regency, South 
Erny Wahdini et al., J Adv Educ Philos, Apr, 2021; 5(4): 110-115

Kalimantan Province Postal code 70613. With the vision of "realizing children are ready to enter basic education based on faith and piety, self-confidence, virtue, and behavior politely" as for the vision, namely 1. Implement a quality learning process produce children who excel. 2. Carry out a learning process that is religious and Islamic nuances. 3. Developing a learning process that is skillful, healthy, smart, and has high character.

\section{Geographical Conditions}

From a geographical aspect, the location of the PAUD "Tutwuri Handayani II" assisted by the Banjar District Education Office, which is located on Jalan Pendidikan, Martapura district, is at a coordinate point between 30-40 LS and between 1140-1150 East Longitude, PAUD "Tutwuri Handayani II" has advantages. from a very strategic location because it is located approximately 100 meters from the Banjar district Education Office and approximately 500 meters from Jalan A. Yani Martapura, to be precise in the area of RT 01 Kelurahan Jawa, District Martapura district Banjar South Kalimantan Province. The location data was obtained from observation activities before carrying out data collection through document study, and interviews with several related respondents such as the Head of the PAUD Education Development Division and the Education Office of the Banjar District Education Office, managers, and PAUD educators guided by Mrs. at the time of writing he served as the manager of the PAUD "Tutwuri Handayani II" Martapura.

PAUD "Tutwuri Handayani II" Martapura is located in an area that is not an urban environment, but rather a phenomenon of suburban areas that are growing rapidly and increasingly densely populated due to the development of housing complexes around the Sungai Paring Village area. The institution is located \pm $4 \mathrm{~km}$ from the center of the Banjar district government. From the Sungai Paring Urban Village Office, data on the population of Sungai Paring Village were obtained according to the results of the data collection by the Central Bureau of Statistics for 2019/2020, the population was 85,827 people consisting of 44,315 men and 41,512 women. From that amount, it is known that the number of children aged 0-6 years is 1,500 . Thus, it can be clearly seen that the research location has the potential for the development of the PAUD program, even though in the Martapura sub-district several PAUD institutions both formal and non-formal have been established but because the level of parental awareness of education is getting higher and economic growth is quite good because is no longer a rural economic phenomenon but has led to economic progress that has an urban nuance with people with diverse professions and livelihoods ranging from civil servants, private employees, traders, laborers/factory workers, and other entrepreneurs. The surrounding PAUD institutions are not an obstacle but rather a motivator to compete with each other fairly.

\section{Condition of Educators and Education Personnel}

In the 2019/2020 school year, PAUD Tutwuri

Handayani II Martapura in the Child Care Park (TPA) program has seven (7) educators. Four (4) educators have Diploma II educational background, and three (3) people have high school education background. All educators have received technical training on early childhood education learning orientation.

Employment Data of the Tutwuri Handayani II Martapura Children's Park (TPA)
\begin{tabular}{|l|l|}
\hline No & Manpower Total Description \\
\hline 1 & TPA Manager 3 People Data was taken on 02 September 2019 \\
\hline 2 & Educator Coordinator 1 Person \\
\hline 3 & Educators/caregivers 5 people \\
\hline 4 & Cleaning Personnel 1 Person \\
\hline 5 & 1 Person Cooking Officer \\
\hline
\end{tabular}
Source: PAUD Tutwuri Handayani II Martapura

\section{Condition of Students}

Until the sixth year of the implementation of the Tutwuri Handayani II Martapura Child Care Park (TPA) program, namely in the 2019/2020 school year, the number of students increased from previous years. Given the strategic location of the TPA which is the goal of working parents to entrust their children while they are working. And supported by adequate learning facilities using learning centers for children's play activities.
Data on the condition of TPA Tutwuri Handayani II Martapura students

\begin{tabular}{|l|l|l|l|l|}
\hline \multirow{2}{*}{ No } & \multirow{2}{*}{ Program } & \multicolumn{2}{|l|}{ Peserta Didik } & Jumlah \\
\cline { 3 - 5 } & & $\mathrm{L}$ & $\mathrm{P}$ & \\
\hline 1 & TPA & 10 & 13 & 23 \\
\hline
\end{tabular}

Source: PAUD Tutwuri Handayani II Martapura

\section{Program and Learning Menu Structure Learning Program}

Tutwuri Handayani II Martapura Child Care Park learning program, refers to the 2013 PAUD Curriculum which means that it is a learning program that is not patent in nature or does not have to be rigidly followed, this learning program is developed by 
Erny Wahdini et al., J Adv Educ Philos, Apr, 2021; 5(4): 110-115

managers and educators tailored to the child's development stage.

In this learning system, children learn through playing activities in play centers that have been prepared by educators or institutions. Sentra means a center, so what is meant by a center is a center for children's play activities. The number of play centers opened for children's play activities cannot be determined. It all depends on the needs and capabilities of each PAUD institution. So, centers can develop along with the development of learning needs and the ability of PAUD institutions to provide play centers for children. But what really matters is the quality of the play itself which must be developed and perfected. Therefore, it is not the quantity of the centers that becomes a measure, but rather the quality of children's plays activities in the play center.

\section{Learning Structure}

For the learning structure there is an Age Group: The learning menu is directed at achieving competencies in accordance with the level of growth and development of the child. In terms of levels of growth and development, children are divided into age groups as a normative reference for the normal level.

Development aspects, as for development aspects each age group consists of:

a) Development of moral and religious values

b) Physical development

c) Language development

d) Cognitive development

e) Emotional social development

f) Art development

Competencies and Learning Outcomes, Competencies and learning outcomes to be achieved in each aspect of development are;

a) In the aspect of developing moral and religious values, the competencies that will be achieved are the ability to do worship, know and believe in God's creation and love others.

b) In the aspect of physical development, competence and learning outcomes to be achieved are the ability to manage and body skills including movements that control body movements, fine movements and gross movements, as well as receiving sensory stimuli (five senses).

c) In the aspect of developing language skills, competencies and learning outcomes that will be achieved are the ability to use language and understand language passive and can communicate effectively which is useful for thinking and learning.

d) In the aspect of developing cognitive abilities, competencies and learning outcomes that will be achieved are the ability to think logically, critically, give reasons, solve problems, and find causal relationships. e). In the aspect of socio-emotional development, the competence and learning outcomes to be achieved are the ability to recognize the natural environment, the social environment, the role of society, and respect for social and cultural diversity. And able to develop self-concept, positive attitude towards learning, self-control, and a sense of belonging

e) In the aspect of art development, the competence and learning outcomes to be achieved are the ability to be sensitive to rhythm, tone, bar, various creative works.4). Ability indicators, ability indicators are specific and measurable learning outcomes in one basic competency. The indicators of ability in this educational activity program are indicators of minimum ability which are arranged based on the gradation of ability levels.

\section{Exposure to Data and Findings}

Based on the discussion on the implementation of the Non-formal Early Childhood Education (PAUD) program for the Child Care Park (TPA) at the Tutwuri Handayani Martapura foundation, starting from planning to evaluating success, the following conclusions can be drawn:

\section{1) Planning}

Statement according to Mrs. Nani Hartati: "My fellow educators are always involved in planning annual, semester, monthly, weekly and daily learning plans, so that if any of us don't understand the plan, we immediately discuss it with other educators and are assisted by the manager." (W/NH/P/17-10-2019)

\section{There are two plans carried out, namely}

a. The planning of TPA Tutwuri Handayani II includes $5 \mathrm{~W}+1 \mathrm{H}$ elements, namely: what, why, where, when, who and how.

b. Planning refers to a mechanism because it involves the parties involved in the institution.

\section{2) Implementation}

"The implementation of the learning process is carried out according to the learning plan that has been prepared and must be in accordance with the early childhood learning system, which is based on the stages and processes of child development, using various kinds of educational play tools, activities take place in a pleasant atmosphere, there is collaboration of educators to help each other in the learning process, because without helping each other it is impossible for learning to be carried out well and smoothly." (W/NH/P/29-102019).

Based on the results of the interview above, the implementation of the Child Care Park (TPA) has referred to the planning that has been made and mutually agreed upon, based on the educational calendar schedule set by the Banjar district education office, and using centers as learning resources. 


\section{There are two implementations, namely}

a. The implementation of the learning program is in accordance with the plan that has been prepared and agreed upon.

b. The implementation of the learning program refers to the generic learning menu from the PAUD Directorate.

\section{3) Supervision}

"The supervision that I do as far as possible is not known by the educators, my goal is to get an objective picture of the implementation of the learning carried out by the educators, the supervision I do, among others, is carried out in the classroom or outside the classroom when the children play freely." (W/H/P/29-10-2019) according to one of the managers when interviewed.

a. Supervision is carried out by managers in an effort to provide guidance to educators, to improve the implementation of educational services provided to children.

b. The supervision carried out by PAUD supervisors is still not optimal, so supervision is only carried out by the manager.

\section{4) Learning}

a. Learning uses centers as learning resources.

b. The center used as a learning resource refers to the Regulation of the Minister of Education and Culture of the Republic of Indonesia number 146 concerning the 2013 PAUD Curriculum.

\section{5) Energy}

According to one of the educators: "My last education was high school and as an educator it has been around 4 years, currently I am still studying in semester 6 of the S1 PAUD program at UT. Before I took part in teaching at this TPA for about 2 months I did an apprenticeship first, because in this TPA there is a requirement for the teaching staff to have a letter of experience working in PAUD. In addition, it is also to improve the ability to care for children Our early years are often included in trainings organized by the Education Office.” (W/MH/P/29-10-2019).

a. Manpower at the institution has not yet referred to the qualification standards of a PAUD educator as mandated by Government Regulation (PP) number 19 concerning National Education Standards due to limited human resources, but the implementation of upgrading the qualifications of educators at TPA is still in process.

b. In an effort to improve the competence of teaching staff, educators take part in technical trainings on early childhood learning.

\section{6) Financing}

a. Funding comes from pilot stimulant funds through the central government in 2003 and from parents' self-help.

b. Financing is guided by plans drawn up and agreed upon by the parties involved.

\section{7) Success Evaluation}

a. The evaluation of success is carried out by the manager together with parents and the Education Office.

b. The evaluation of success is guided by the implementation of PAUD Nonformal issued by the PAUD Directorate.

\section{CONCLUSION}

The implementation of the Child Care Park (TPA) Non-formal Early Childhood Education (PAUD) program at the Tutwuri Handayani Martapura Foundation, starting from planning to evaluating success, fulfills the criteria with details on; 1) planning, 2) implementation, 3) supervision, 4) learning, 5) energy, 6) financing, and 7) success evaluation declared to meet the standard.

\section{REFERENCE}

1. Djumali. (2014). Landasan Pendidikan. Gava Media Jogjakarta.

2. Sutrisno, V. L. P., \& Siswanto, B. T. (2016). Faktorfaktor yang mempengaruhi hasil belajar siswa pada pembelajaran praktik kelistrikan otomotif SMK di Kota Yogyakarta. Jurnal pendidikan vokasi, 6(1), 111-120.

3. Kurniawan. (2017). Pengantar Pendidikan. Salim Media Indonesia Jambi.

4. Trahati, M. R. (2015). Implementasi Pendidikan Karakter Peduli Lingkungan Di Sekolah Dasar Negeri Tritih Wetan 05 Jeruklegi Cilacap. Basic education, 5(12).

5. Mawardi, M. (2014). Pemberlakuan Kurikulum SD/MI Tahun 2013 dan Implikasinya Terhadap Upaya Memperbaiki Proses Pembelajaran Melalui PTK. Scholaria: Jurnal Pendidikan dan Kebudayaan, 4(3), 107-121.

6. Manulang, R. (2006). Suatu Tinjauan Tentang Pemberantasan Tindak Pidana Narkotika Menurut Undang-Undang Nomor 22 Tahun1997 Studi Kasus Pengadilan Negeri Sibolga (Doctoral dissertation, Universitas Medan Area).

7. Anggito, A., \& Setiawan, J. (2018). Metodologi penelitian kualitatif. CV Jejak (Jejak Publisher).

8. Moleong, Lezy, J. (2017). Metode Penelitian Kualitatif. Bandung : PT Remaja Rosdakarya.

9. Nasution, S. (2016). Metodologi Penelitian Naturalistik Kualitatif. Bandung : Tarsito.

10. Miles, M.B., \& Hubberman, A.M. (1984). Qualitative Data Analysis. Beverly Hills: Sage Publication.

11. Bogdan, R., \& Biklen, S. K. (1997). Qualitative research for education. Boston, MA: Allyn \& Bacon. 